\title{
Genetic Divergence in Groundnut (Arachis hypogaea L.) using RAPD
}

\author{
Yaikhom Vivekananda ${ }^{1 *}$, Pramesh Khoyumthem ${ }^{2}$, Mutum Suraj Singh ${ }^{3}$, \\ Konsam Cha Shyamananda ${ }^{3}$ and N. Brajendra Singh ${ }^{1}$ \\ ${ }^{1}$ Department of Plant Breeding and Genetics, College of Agriculture, Central Agricultural \\ University, Imphal-795004, India \\ ${ }^{2}$ AICRP(Groundnut), Central Agricultural University, India \\ ${ }^{3}$ Farmer FIRST, Imphal Centre, Central Agricultural University, India \\ *Corresponding author
}

\begin{tabular}{|l|}
\hline Ke y w o r d s \\
RAPD, Groundnut, \\
Genetic Divergence \\
\hline Article Info \\
\hline $\begin{array}{l}\text { Accepted: } \\
18 \text { August } 2019 \\
\text { Available Online: } \\
\text { 10 September } 2019\end{array}$ \\
\hline
\end{tabular}

A B S T R A C T
Twenty four genotypes of Arachis hypogaea (L.), of which 12 genotypes belonging to Virginia and 12 belonging to Spanish varieties were used to study the genetic divergence within its botanical varieties using RAPD. 16 primers belonging to OPH were used in the study. Out of the 16 primers utilized, 36 and 37 bands were produced in Virginia and Spanish group, respectively. Out of the total bands produced, 18 and 20 bands were polymorphic for Virginia and Spanish group, respectively. Jaccard's similarity coefficient for Virginia group ranged from 0.09 to 0.78 and for Spanish group, it ranged from 0.13 to 0.88 . A dendrogram was constructed using the similarity matrix value as determined from RAPD data for 24 groundnut genotypes. From the similarity coefficient it was found that the genotypes HNG 137 and ICGS 76 (0.09); HNG 137 and ICGV $87846(0.09)$ showed maximum diversity among all genotypes for the Virginia group whereas the genotypes JSP 48 and K 1451 (0.78); K 1451 and K 1468 (0.78) showed the maximum similarity. Similarly, for the Virginia group the genotypes CSMG 2006-6 and J 71 (0.13); CSMG 2006-6 and RTNG 1 (0.13); K 1470 and RTNG 1 (0.013); J 71 and K 1470 showed maximum diversity whereas Dh 218 and K 1392 (0.88) showed the maximum similarity. The dendrogram clearly divided 12 genotypes of Virginia and Spanish groundnut genotypes into 4 and 5 clusters, respectively. The genetic relationships estimated can be useful for hybridization in the future groundnut improvement programme.

\section{Introduction}

Groundnut (Arachis hypogaea L.) is an important crop among oilseeds grown in the world. It is native to South America, where it is well distributed over a wide environment. It belongs to the family Fabaceae. It is known by many names and the most common among them are monkey nut, goober nut and peanut. It is a self-pollinated crop, allotetraploid with diploid chromosome number $2 n=40$.

Botanically, cultivated groundnut can be classified into two sub-species, which mainly 
differed in a branching pattern. Bunting (1955, 1958) divided the cultivated groundnut into two large botanical groups on the basis of branching patterns (Subspecies hypogaea with alternate branching and fastigiata with sequencial branching pattern). Subspecies hypogaea are further divided into botanical varieties viz., var. hypogaea (Virginia) and var. hirsuta and subspecies fastigiata into var. fastigiata (Valencia); var. vulgaris (Spanish); var. peruvian and var. aequatoriana.

India is having the world largest area under groundnut (6 million ha) with $980 \mathrm{~kg} / \mathrm{ha}$, which is next to China $(3460 \mathrm{~kg} / \mathrm{ha})$. The productivity of groundnut in India is very low, the USA stands first for productivity, that is, $3710 \mathrm{~kg} / \mathrm{ha}$. (Anonymous, 2012). In India groundnut is mainly grown in Gujarat, Andhra Pradesh, Tamil Nadu, Karnataka and Maharashtra with $32.37 \%, 18.53 \%, 16.39 \%$, $9.43 \%, 6.61 \%$ respectively (Anonymous, 2011).

In Manipur, groundnut is mainly cultivated in kharif season and area under this crop is very small due to lack of suitable varieties for this region. The state has about 2,89,826 ha of total cropped area (Department of Agriculture, CIC Manipur) and there is a possible niche for groundnut in about $20 \%$ of this area. Paddy (Oryza sativa L.) is the major kharif crop in this state and after the harvesting of Paddy, the land is either left fallow or planted with Mustard (Brassica sp.). So, the introduction of suitable rabi groundnut varieties can also utilized in this fallow land. In order to develop such suitable varieties, a systematic breeding approach has to be adopted.

RAPD markers are commonly used because they are quick and simple to obtain, enabling genetic diversity analysis in several types of plant material such as natural populations, the population in breeding programmes and germplasm collections. It does not require any sequential data because arbitrary DNA sequence is used as a single primer of amplified sequence which could be species or strain-specific and constitute identifying the profile of organism (Ferreira and Grattupaglia, 1996). When cost-efficient and simplicity were considered RAPD proves to be superior (Williams et al., 1990). RAPD has been used in the analysis of genetic distance in different plant species (Lashermes et al., 1996; Samec and Nesinec, 1996; Colombo et al., 2000).

Molecular markers have been proved to be an important tool in the characterization and genetic diversity analysis within and between species and populations.

It has been shown that different markers might reveal different classes of variation (Powell et al., 1996; Russell et al., 1997) is correlated with the genome fraction surveyed by each kind of marker, their distribution throughout the genome and extend of the DNA target which is analyzed by each specific assay (Davila et al., 1999).

\section{Materials and Methods}

\section{Plant Material}

The seeds of 24 different genotypes of groundnut were obtained from the Department of Plant Breeding and Genetics, College of Agriculture, CAU, Imphal. Leaves were collected at 15 days after sowing. The experimental materials which were used in the present study are given in Table 1 and 2 .

\section{List of Primers}

A set of 16 RAPD primers were used for PCR amplification and the primers were procured from Eurofins Genomics India Private Limited (previously Operon), Banglore. The details of primer code sequence of the primer and GC contents are given in table 3 . 


\section{DNA Isolation}

DNA isolation was done according to the DNA isolation method (Porebski et al., 1997) with a slight modification. The leaf sample of $0.1 \mathrm{~g}$ of each genotype of groundnut was taken and grinned in mortar pestle using liquid nitrogen. The mixer was put in a micro centrifuge tube separately for each genotype. 1 $\mathrm{ml}$ of $60{ }^{\circ} \mathrm{C}$ extraction buffer with $10 \mathrm{mg}$ $\mathrm{PVP} / 100 \mathrm{mg}$ of leaf tissue was added to each sample tubes and were incubated at $60{ }^{\circ} \mathrm{C}$ in water bath for 60 minutes. After that the sample tubes were removed from water bath and made it cool at room temperature for 4 to 6 minutes. The same amount of chloroform: isoamyl (24:1) was added to each sample tubes and mixed by inversion to form emulsion. After mixing thoroughly, the sample tubes were spun at $3000 \mathrm{rpm}$ for 20 minutes in a centrifuge at $4{ }^{\circ} \mathrm{C}$. The upper phase i.e the aqueous solution was taken to new $1.5 \mathrm{ml}$ micro centrifuge tube using widebore pipette tip $(1000 \mu 1)$. Then the process of chloroform:isoamyl extraction was repeated again. In the final aqueous solution recovered, $1 / 2$ volume of $5 \mathrm{M} \mathrm{NaCl}$ and 2 volumes of icecold $\left(-20^{\circ} \mathrm{C}\right) 95 \%$ ethanol were added and mixed by inversion, then the sample tubes were kept at $4^{\circ} \mathrm{C}$ to precipitate overnight. On the next day the sample tubes were spun at $3000 \mathrm{rpm}$ for 6 minutes and the supernatant from each sample tubes was poured off. Then the pellet was washed with ice-cold $\left(4^{\circ} \mathrm{C}\right)$ ethanol. After that the samples were dried in laminar airflow for approximately one hour. 3 $\mu l$ RNase A $(10 \mathrm{mg} / \mathrm{ml})$ was added to each sample tubes and incubated in water-bath at $37^{\circ} \mathrm{C}$ for 1 hour.

Then $3 \mu$ proteinase $\mathrm{K}(1 \mathrm{mg} / \mathrm{ml})$ was added and again incubated at $37^{\circ} \mathrm{C}$ for 30 minutes. $150 \mu \mathrm{l}$ of tris saturated phenol $(\mathrm{pH} 8)$ and 150 $\mu \mathrm{l}$ of chloroform were added to each sample tubes and vortex briefly then spun in centrifuge at $14,000 \mathrm{rpm}$ for 15 minutes at $4^{\circ} \mathrm{C}$. The upper layer was collected from each sample tubes and transferred to new $1.5 \mathrm{ml}$ micro centrifuge tubes, then $100 \mu 1$ of TE buffer and 1/10 vol. $2 \mathrm{M} \mathrm{Na}$ acetate was added to the phenol phase. The sample tubes were kept overnight in $-20^{\circ} \mathrm{C}$ and then spun at $14,000 \mathrm{rpm}$ for 20 minutes in centrifuge at $4^{\circ} \mathrm{C}$ on the next day.

After that, the supernatant was drained off from each sample tubes and made it dry in laminar airflow for approximately 1 hour. Then $400 \mu 1$ of TE buffer was added to each sample tubes and allowed it for complete resuspension.

The quantification of DNA was done by observing its absorbance at $260 \mathrm{~nm}$ and 280 $\mathrm{nm}$ wavelengths by using a spectrophotometer (Aquarius Cecil CE 7200) and quality of gel is analyzed by running on $0.8 \%$ agarose gel.

\section{PCR Analysis}

PCR was performed by using 16 RAPD primer and Epicentre FailSafe ${ }^{\mathrm{TM}}$ PCR system with a total volume of $20 \mu \mathrm{L}$, containing $2 \mu \mathrm{L}$ template DNA, $10 \mu \mathrm{L} 2 \mathrm{X}$ premix, $0.5 \mu \mathrm{M}$ of each primer and $1.25 \mathrm{U}$ of an enzyme (Epicentre, USA). PCR amplification (2720 Thermal Cycler, Applied Biosystems, California, USA) was carried out using a standard PCR cycle was condition: an initial denaturation step at $94{ }^{\circ} \mathrm{C}$ for $5 \mathrm{~min}$, followed by 38 cycles of $94{ }^{\circ} \mathrm{C}$ for $1 \mathrm{~min}, 34^{\circ} \mathrm{C}$ for 1 min, and $72{ }^{\circ} \mathrm{C}$ for $2 \mathrm{~min}$; the final extension was held for $5 \mathrm{~min}$. Following the amplification, the PCR products were loaded on 1.4 Agarose Gel which was prepared in $1 \mathrm{X}$ TAE buffer. The amplified product was electrophoresis for 1.5 hours at $90 \mathrm{~V}$ and stained with ethidium bromide $(10 \mathrm{mg} / \mathrm{ml})$. After separation, the gel was viewed under and photographed by using Gel Doc XR+ (Bio-Rad, California, USA) gel documentation system. 
Scoring of RAPD analysis and Statistical Analysis for similarity coefficient

DNA bands were designated on the basis of their molecular size corresponding to loaded DNA ladder (100 bp). The presence of each band was scored as ' 1 ' and its absence as ' 0 .

The scores $(0$ or 1$)$ for each band obtained were entered in the form of a rectangular data matrix (qualitative data matrix) and the pairwise association coefficients were calculated from the qualitative data matrix using Jaccard's similarity coefficient (Jaccard, 1901).

\section{Results and Discussion}

\section{DNA isolation, purification and quantification}

The concentration of DNA prepared varies from $53.20 \mathrm{ng} / \mu \mathrm{l}$ (CSMG 2006-6) to 119.50 $\mathrm{ng} / \mu \mathrm{l}$ (RG 530) respectively as shown in table 4. The integrity of the isolated DNA was verified by visualization of DNA on 0.8 per cent Agarose gel with $1 \mathrm{kbp}$ DNA ladder. The quality of DNA was determined by the $\mathrm{A}_{260} / \mathrm{A}_{280}$ ratio which ranged from 1.46 to 1.91 as shown in table 4.

\section{RAPD analysis}

Sixteen random decamer primers obtained from Eurofins Genomics India Private Limited (previously Operon), Banglore having high per cent of $\mathrm{G}+\mathrm{C}$ contents were used for RAPD analysis in 24 genotypes of groundnut (12 Virginia and 12 Spanish) for detecting polymorphism and showed the percentage of polymorphism ranging from 0 to $100 \%$.

The DNA amplification and polymorphism generated among various genotypes of groundnut using random primers are presented in table 5 and 6 . Out of 16 primers, the maximum band were produced in primer $\mathrm{OPH}-17$ with 4 bands and all of them were polymorphic for both Virginia and Spanish group while a minimum of 1 band was produced in primer $\mathrm{OPH}-1, \mathrm{OPH}-3$, OPH-7 and OPH-9 for both the groundnut group. For Virginia group out of 36 bands produced 18 are found to be a polymorphic while for Spanish out of 37 bands produced 20 are polymorphic.

\section{Jaccard's similarity coefficient and cluster analysis}

The RAPD score obtained by using Bio-Rad ImageLab 3.0 software was utilized to produce Jaccard's similarity coefficient separately for two groundnut group (Virginia and Spanish) and data were subjected to UPGMA (Unweighted Pair Group Method with Arithmetic Mean) and dendrogram was generated using NTSYSpc version 2.2 (Rohlf, 1998) which is presented in Table 7, 8, Fig. 1 and Fig. 2.

DNA isolation, purification and quantification

The concentration of DNA prepared were found to vary from $53.20 \mathrm{ng} / \mu \mathrm{l}$ to 119.50 $\mathrm{ng} / \mu \mathrm{l}$ respectively which shows there was enough DNA content in the sample to carried out the PCR process. The quality of DNA was determined by the $\mathrm{A}_{260} / \mathrm{A}_{280}$ ratio which ranged from 1.46 to 1.91 which indicates a good quality plant DNA.

\section{RAPD analysis}

Sixteen random decamer primers obtained from Eurofins Genomics India Private Limited (previously Operon), Banglore was used for RAPD analysis in 24 genotypes of groundnut (12 Virginia and 12 Spanish) of which and these primers showed the percentage of polymorphism ranged from 0 to $100 \%$. 
Among 16 primers amplified, the primer code OPH-5, OPH-7, OPH-8, OPH-10, OPH-12, OPH-13, OPH-14, OPH-17, OPH-18, OPH-19 and $\mathrm{OPH}-20$ gave polymorphic bands for both Virginia and Spanish group, whereas, primer OPH-15 gave polymorphic only in Spanish group. The molecular size of the band ranged between $300 \mathrm{bp}$ to $800 \mathrm{bp}$. OPH-17 and OPH19 gave the highest number of bands i.e. 4 for both Virginia and Spanish group.
The primer $\mathrm{OPH}-8, \mathrm{OPH}-14, \mathrm{OPH}-18$ and OPH-20 gave 3 bands each for Virginia group and in Spanish group OPH-8, OPH-13, OPH14, OPH-18 and OPH-20 gave 3 bands each. Primer OPH-1, OPH-3, OPH-7 and OPH-9 gave minimum 1 band each and the remaining primer gave 2 bands each for both Virginia and Spanish group. An average of 2.25 and 2.31 bands per primer was produced for Virginia and Spanish group, respectively.

Table.1 Virginia group

\begin{tabular}{|l|l|l|}
\hline S. No. & Genotype & Source \\
\hline $\mathbf{1}$ & BAU 13 & BAU, Kanke \\
\hline $\mathbf{2}$ & CSMG 2006-26 & ARS, Chintamani \\
\hline $\mathbf{3}$ & HNG 137 & RAU, Hanumangard \\
\hline $\mathbf{4}$ & ICGS 76 & ICRISAT, Hyderabad \\
\hline $\mathbf{5}$ & ICGV 87846 & ICRISAT, Hyderabad \\
\hline $\mathbf{6}$ & JSP 48 & JAU, Junagadh \\
\hline $\mathbf{7}$ & JSP 49 & JAU, Junagadh \\
\hline $\mathbf{8}$ & JSSP 37 & JAU, Junagadh \\
\hline $\mathbf{9}$ & K 1451 & ARS, Kadiri \\
\hline $\mathbf{1 0}$ & K 1468 & ARS, Kadiri \\
\hline $\mathbf{1 1}$ & RG 530 & IGKV, Raipur \\
\hline $\mathbf{1 2}$ & RG 578 & IGKV, Raipur \\
\hline
\end{tabular}

Table.2 Spanish group

\begin{tabular}{|l|l|l|}
\hline S. No. & Genotype & Source \\
\hline $\mathbf{1}$ & CSMG 2006-6 & ARS, Chintamani \\
\hline $\mathbf{2}$ & CTMG 7 & ARS, Chintamani \\
\hline $\mathbf{3}$ & Dh 218 & UAS, Dharwad \\
\hline $\mathbf{4}$ & J71 & ORS, Jalgaon \\
\hline $\mathbf{5}$ & K1333 & ARS, Kadiri \\
\hline $\mathbf{6}$ & K1392 & ARS, Kadiri \\
\hline $\mathbf{7}$ & K1470 & ARS, Kadiri \\
\hline $\mathbf{8}$ & RTNG 1 & IGKV, Raipur \\
\hline $\mathbf{9}$ & TCGS 876 & RARS, Tirupati \\
\hline $\mathbf{1 0}$ & TCGS 901 A & RARS, Tirupati \\
\hline $\mathbf{1 1}$ & TG 68 & ORS, Tindivanam \\
\hline $\mathbf{1 2}$ & UG 6 & MPUA\& , Udaipur \\
\hline
\end{tabular}


Table.3 Detail of RAPD primer used in molecular analysis of groundnut germplasm

\begin{tabular}{|l|l|l|l|}
\hline S. No. & Primer* & Sequence 5' to $\mathbf{3}^{\prime}$ & GC-content $\mathbf{( \% )}$ \\
\hline $\mathbf{1 .}$ & OPH-01 & GGTCGGAGAA & 60 \\
\hline $\mathbf{2 .}$ & OPH-03 & AGACGTCCAC & 60 \\
\hline $\mathbf{3 .}$ & OPH-04 & GGAAGTCGCC & 70 \\
\hline $\mathbf{4 .}$ & OPH-05 & AGTCGTCCCC & 70 \\
\hline $\mathbf{5 .}$ & OPH-07 & CTGCATCGTG & 60 \\
\hline $\mathbf{6 .}$ & OPH-08 & GAAACACCCC & 60 \\
\hline $\mathbf{7 .}$ & OPH-09 & TGTAGCTGGG & 60 \\
\hline $\mathbf{8 .}$ & OPH-10 & CCTACGTCAG & 60 \\
\hline $\mathbf{9 .}$ & OPH-12 & ACGCGCATGT & 60 \\
\hline $\mathbf{1 0 .}$ & OPH-13 & GACGCCACAC & 70 \\
\hline $\mathbf{1 1 .}$ & OPH-14 & ACCAGGTTGG & 60 \\
\hline $\mathbf{1 2 .}$ & OPH-15 & AATGGCGCAG & 60 \\
\hline $\mathbf{1 3 .}$ & OPH-17 & CACTCTCCTC & 60 \\
\hline $\mathbf{1 4}$. & OPH-18 & GAATCGGCCA & 60 \\
\hline $\mathbf{1 5}$. & OPH-19 & CTGACCAGCC & 70 \\
\hline $\mathbf{1 6 .}$ & OPH-20 & GGGAGACATC & 60 \\
\hline
\end{tabular}

*Operon primer code.

Fig.1 Dendrogram showing relationship among 12 Virginia group groundnut genotypes generated by UPGMA analysis based on RAPD

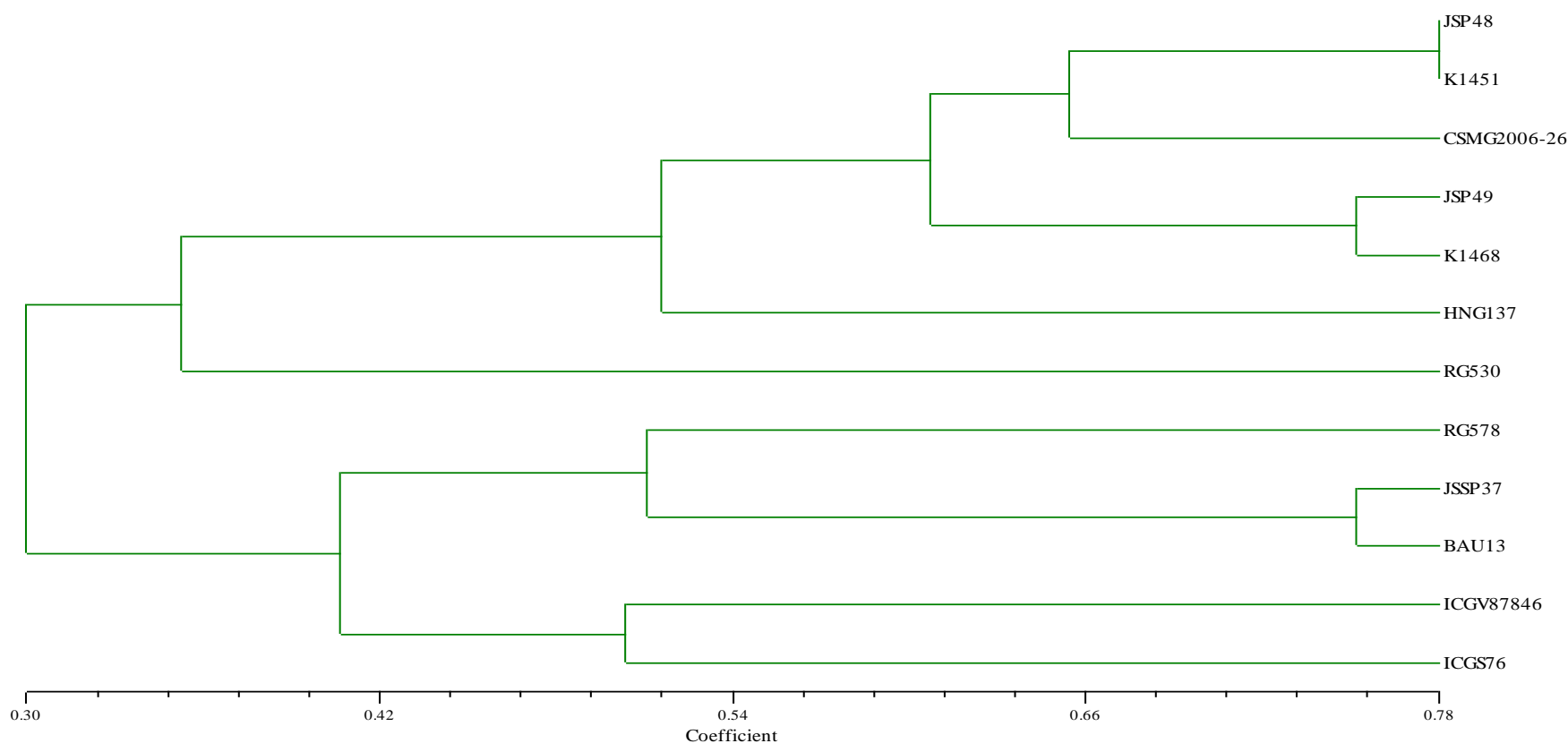


Int.J.Curr.Microbiol.App.Sci (2019) 8(9): 1535-1549

Table.4 Concentration of DNA in groundnut genotypes

\begin{tabular}{|c|c|c|c|c|}
\hline S. No. & Genotype & Group & $260 / 280$ & Concentration ng/ul \\
\hline 1 & BAU 13 & Virginia & 1.68 & 88.15 \\
\hline 2 & CSMG 2006-6 & Spanish & 1.72 & 53.20 \\
\hline 3 & CSMG 2006-26 & Virginia & 1.69 & 56.40 \\
\hline 4 & CTMG 7 & Spanish & 1.65 & 84.10 \\
\hline 5 & Dh 218 & Spanish & 1.58 & 66.60 \\
\hline 6 & HNG 137 & Virginia & 1.63 & 69.50 \\
\hline 7 & ICGS 76 & Virginia & 1.64 & 78.55 \\
\hline 8 & ICGV 87846 & Virginia & 1.68 & 58.50 \\
\hline 9 & J71 & Spanish & 1.67 & 122.00 \\
\hline 10 & JSP 48 & Virginia & 1.46 & 55.10 \\
\hline 11 & JSP 49 & Virginia & 1.57 & 810 \\
\hline 12 & JSSP 37 & Virginia & 1.65 & 84.10 \\
\hline 13 & K1333 & Spanish & 1.67 & 104.50 \\
\hline 14 & K1392 & Spanish & 1.63 & 86.20 \\
\hline 15 & K 1451 & Virginia & 1.91 & 76.10 \\
\hline 16 & K 1468 & Virginia & 1.50 & 72.80 \\
\hline 17 & K1470 & Spanish & 1.65 & 81.25 \\
\hline 18 & RG 530 & Virginia & 1.60 & 119.50 \\
\hline 19 & RG 578 & Virginia & 1.62 & 78.00 \\
\hline 20 & RTNG 1 & Spanish & 1.66 & 148.00 \\
\hline 21 & TCGS 876 & Spanish & 1.56 & 65.30 \\
\hline 22 & TCGS $901 \mathrm{~A}$ & Spanish & 1.65 & 93.40 \\
\hline 23 & TG 68 & Spanish & 1.63 & 70.10 \\
\hline 24 & UG 6 & Spanish & 1.63 & 98.50 \\
\hline
\end{tabular}


Table.5 Polymorphic information of RAPD primers analysed for Virginia group

\begin{tabular}{|l|l|l|l|l|l|}
\hline S. No. & $\begin{array}{l}\text { Primer } \\
\text { code }\end{array}$ & Sequences (5'to 3') & $\begin{array}{l}\text { Total } \\
\text { Number } \\
\text { of } \\
\text { bands(a) }\end{array}$ & $\begin{array}{l}\text { Total Number } \\
\text { of } \\
\text { polymorphic } \\
\text { bands(b) }\end{array}$ & $\begin{array}{l}\text { Polymorphism } \\
\text { \% (b/a X 100) }\end{array}$ \\
\hline $\mathbf{1}$ & OPH-01 & GGTCGGAGAA & 1 & 0 & 0 \\
\hline $\mathbf{2}$ & OPH-03 & AGACGTCCAC & 1 & 0 & 0 \\
\hline $\mathbf{3}$ & OPH-04 & GGAAGTCGCC & 2 & 0 & 0 \\
\hline $\mathbf{5}$ & OPH-05 & AGTCGTCCCC & 2 & 1 & 50 \\
\hline $\mathbf{6}$ & OPH-07 & CTGCATCGTG & 1 & 1 & 50 \\
\hline $\mathbf{7}$ & OPH-08 & GAAACACCCC & 3 & 2 & 66.7 \\
\hline $\mathbf{8}$ & OPH-09 & TGTAGCTGGG & 1 & 0 & 0 \\
\hline $\mathbf{9}$ & OPH-10 & CCTACGTCAG & 2 & 1 & 50 \\
\hline $\mathbf{1 0}$ & OPH-12 & ACGCGCATGT & 2 & 1 & 50 \\
\hline $\mathbf{1 1}$ & OPH-13 & GACGCCACAC & 2 & 2 & 100 \\
\hline $\mathbf{1 2}$ & OPH-14 & ACCAGGTTGG & 3 & 2 & 66.7 \\
\hline $\mathbf{1 3}$ & OPH-15 & AATGGCGCAG & 2 & 0 & 0 \\
\hline $\mathbf{1 4}$ & OPH-17 & CACTCTCCTC & 4 & 4 & 100 \\
\hline $\mathbf{1 5}$ & OPH-18 & GAATCGGCCA & 3 & 1 & 33.3 \\
\hline $\mathbf{1 6}$ & OPH-19 & CTGACCAGCC & 4 & 1 & 25 \\
\hline & OPH-20 & GGGAGACATC & 3 & 2 & 66.7 \\
\hline & & Total & 36 & 18 & 50 \\
\hline
\end{tabular}

Table.6 Polymorphic information of RAPD primers analysed for Spanish group

\begin{tabular}{|l|l|l|l|l|l|}
\hline S. No. & $\begin{array}{l}\text { Primer } \\
\text { code }\end{array}$ & Sequences (5'to 3') & $\begin{array}{l}\text { Total } \\
\text { Number } \\
\text { of } \\
\text { bands(a) }\end{array}$ & $\begin{array}{l}\text { Total Number } \\
\text { of } \\
\text { polymorphic } \\
\text { bands(b) }\end{array}$ & $\begin{array}{l}\text { Polymorphism } \\
\text { \% (b/a X 100) }\end{array}$ \\
\hline $\mathbf{1}$ & OPH-01 & GGTCGGAGAA & 1 & 0 & 0 \\
\hline $\mathbf{2}$ & OPH-03 & AGACGTCCAC & 1 & 0 & 0 \\
\hline $\mathbf{3}$ & OPH-04 & GGAAGTCGCC & 2 & 0 & 0 \\
\hline $\mathbf{4}$ & OPH-05 & AGTCGTCCCC & 2 & 1 & 50 \\
\hline $\mathbf{5}$ & OPH-07 & CTGCATCGTG & 1 & 1 & 50 \\
\hline $\mathbf{6}$ & OPH-08 & GAAACACCCC & 3 & 2 & 66.7 \\
\hline $\mathbf{7}$ & OPH-09 & TGTAGCTGGG & 1 & 0 & 0 \\
\hline $\mathbf{8}$ & OPH-10 & CCTACGTCAG & 2 & 1 & 50 \\
\hline $\mathbf{9}$ & OPH-12 & ACGCGCATGT & 2 & 1 & 50 \\
\hline $\mathbf{1 0}$ & OPH-13 & GACGCCACAC & 3 & 3 & 100 \\
\hline $\mathbf{1 1}$ & OPH-14 & ACCAGGTTGG & 3 & 2 & 66.7 \\
\hline $\mathbf{1 2}$ & OPH-15 & AATGGCGCAG & 2 & 1 & 0 \\
\hline $\mathbf{1 3}$ & OPH-17 & CACTCTCCTC & 4 & 4 & 100 \\
\hline $\mathbf{1 4}$ & OPH-18 & GAATCGGCCA & 3 & 1 & 33.3 \\
\hline $\mathbf{1 5}$ & OPH-19 & CTGACCAGCC & 4 & 1 & 25 \\
\hline $\mathbf{1 6}$ & OPH-20 & GGGAGACATC & 3 & 2 & 66.7 \\
\hline & & Total & 20 & 54 \\
\hline
\end{tabular}


Table.7 Jaccard's average similarity coefficient for 12 Virginia groundnut genotypes

\begin{tabular}{|c|c|c|c|c|c|c|c|c|c|c|c|c|}
\hline & BAU13 & $\begin{array}{c}\text { CSMG2006- } \\
26\end{array}$ & HNG137 & ICGS76 & $\begin{array}{l}\text { ICGV } \\
87846\end{array}$ & JSP48 & JSP49 & JSSP37 & K1451 & K1468 & RG530 & RG578 \\
\hline BAU13 & 1 & & & & & & & & & & & \\
\hline $\begin{array}{c}\text { CSMG2006- } \\
26\end{array}$ & 0.55 & 1 & & & & & & & & & & \\
\hline HNG137 & 0.25 & 0.54 & 1 & & & & & & & & & \\
\hline ICGS76 & 0.5 & 0.27 & 0.09 & 1 & & & & & & & & \\
\hline $\begin{array}{l}\text { ICGV } \\
87846\end{array}$ & 0.5 & 0.27 & 0.09 & 0.5 & 1 & & & & & & & \\
\hline JSP48 & 0.3 & 0.64 & 0.6 & 0.25 & 0.11 & 1 & & & & & & \\
\hline JSP49 & 0.44 & 0.64 & 0.33 & 0.25 & 0.25 & 0.56 & 1 & & & & & \\
\hline JSSP37 & 0.75 & 0.73 & 0.42 & 0.38 & 0.38 & 0.5 & 0.5 & 1 & & & & \\
\hline K1451 & 0.36 & 0.67 & 0.64 & 0.33 & 0.2 & 0.78 & 0.6 & 0.55 & 1 & & & \\
\hline K1468 & 0.3 & 0.5 & 0.45 & 0.25 & 0.25 & 0.56 & 0.75 & 0.36 & 0.78 & 1 & & \\
\hline RG530 & 0.13 & 0.27 & 0.2 & 0.2 & 0.2 & 0.43 & 0.43 & 0.1 & 0.33 & 0.43 & 1 & \\
\hline RG578 & 0.57 & 0.33 & 0.08 & 0.33 & 0.33 & 0.2 & 0.5 & 0.44 & 0.27 & 0.14 & 0.33 & 1 \\
\hline
\end{tabular}


Table.8 Jaccard's average similarity coefficient for 12 Spanish groundnut genotypes

\begin{tabular}{|c|c|c|c|c|c|c|c|c|c|c|c|c|}
\hline & $\begin{array}{l}\text { CSMG } \\
2006-6\end{array}$ & CTMG7 & Dh218 & J71 & K1333 & K1392 & K1470 & RTNG1 & $\begin{array}{c}\text { TCGS } \\
876\end{array}$ & $\begin{array}{c}\text { TCGS } \\
901 \mathrm{~A}\end{array}$ & TG68 & UG6 \\
\hline CSMG2006-6 & 1 & & & & & & & & & & & \\
\hline CTMG7 & 0.5 & 1 & & & & & & & & & & \\
\hline Dh218 & 0.5 & 0.78 & 1 & & & & & & & & & \\
\hline J71 & 0.13 & 0.38 & 0.38 & 1 & & & & & & & & \\
\hline K1333 & 0.44 & 0.7 & 0.55 & 0.44 & 1 & & & & & & & \\
\hline K1392 & 0.57 & 0.67 & 0.88 & 0.31 & 0.6 & 1 & & & & & & \\
\hline K1470 & 0.6 & 0.5 & 0.5 & 0.13 & 0.44 & 0.57 & 1 & & & & & \\
\hline RTNG1 & 0.13 & 0.3 & 0.3 & 0.36 & 0.17 & 0.2 & 0.13 & 1 & & & & \\
\hline $\begin{array}{c}\text { TCGS } \\
876\end{array}$ & 0.5 & 0.63 & 0.63 & 0.27 & 0.4 & 0.5 & 0.5 & 0.43 & 1 & & & \\
\hline $\begin{array}{l}\text { TCGS } \\
901 \mathrm{~A}\end{array}$ & 0.6 & 0.5 & 0.5 & 0.2 & 0.44 & 0.57 & 0.6 & 0.29 & 0.8 & 1 & & \\
\hline TG68 & 0.5 & 0.63 & 0.63 & 0.19 & 0.4 & 0.5 & 0.5 & 0.43 & 0.67 & 0.5 & 1 & \\
\hline UG6 & 0.21 & 0.4 & 0.4 & 0.69 & 0.57 & 0.43 & 0.21 & 0.29 & 0.2 & 0.21 & 0.29 & 1 \\
\hline
\end{tabular}


Fig.2 Dendrogram showing relationship among 12 Spanish group groundnut genotypes generated by UPGMA analysis based on RAPD

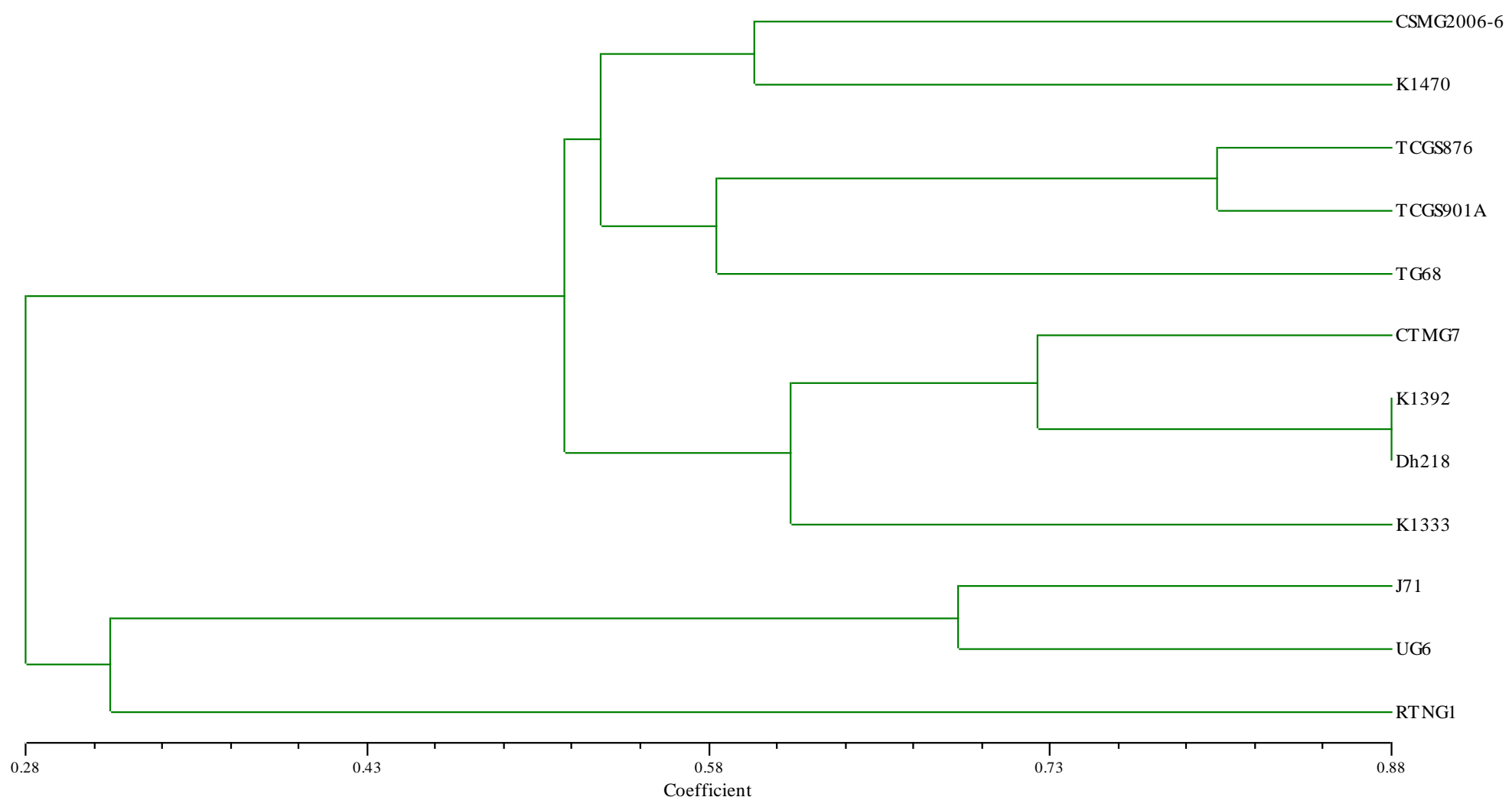


Fig.3 RAPD profile generated through OPH-18 in 12 Virginia genotypes (M: DNA Ladder 100 bp, 1:JSP 48, 2:RG 530, 3:JSP 49, 4:RG 578, 5:K 1468, 6:K1451, 7:CSMG 2006-26, 8:JSSP 37, 9:ICGV 87846, 10:HNG 137, 11:ICGS 76, 12:BAU 13)

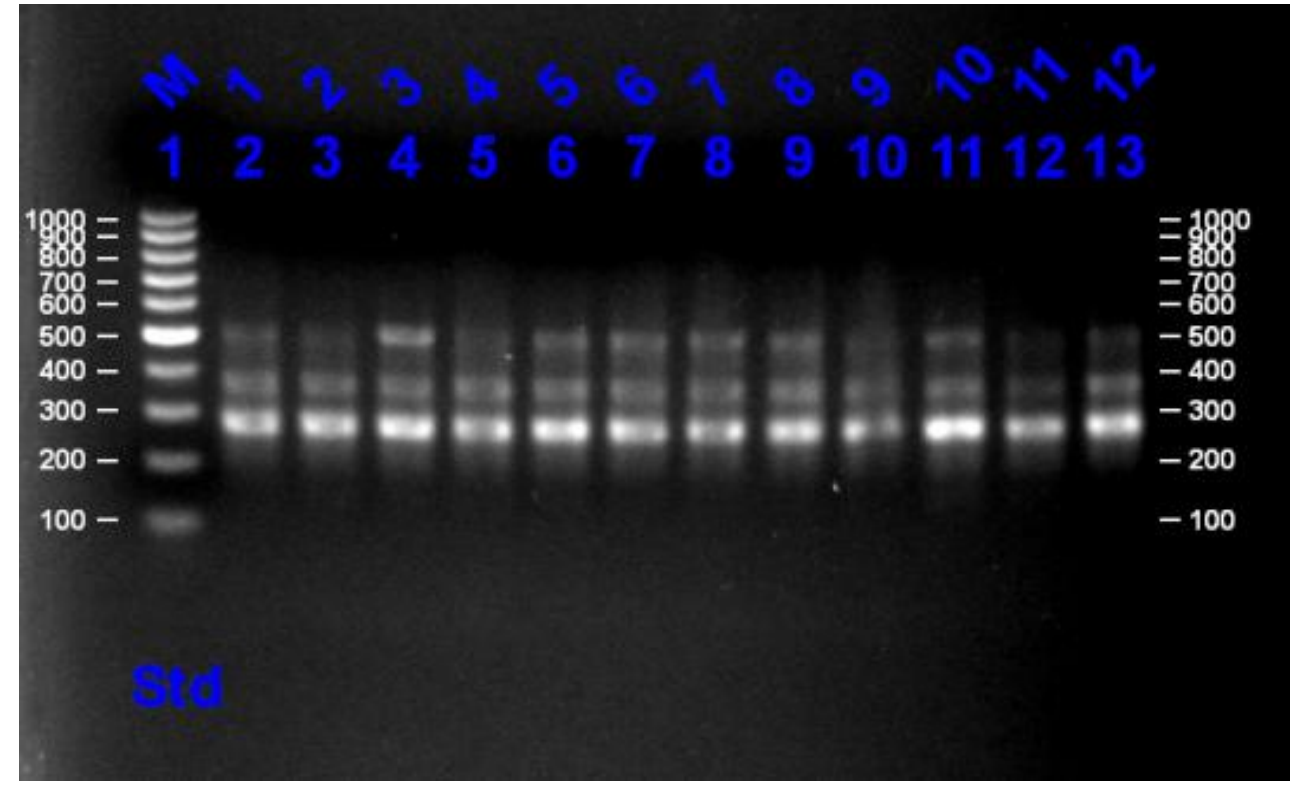

Fig.4 RAPD profile generated through OPH-18 in 12 Spanish genotypes (M:Ladder 100 bp, 13:CSMG 2006-6,14:TCGS 876, 15:TCGS 901A, 16:J71, 17: CTMG 7, 18:TG 68, 19:UG 6, 20:K1470, 21:K1392, 22:RTNG 1, 23:Dh 218, 24:K1333)

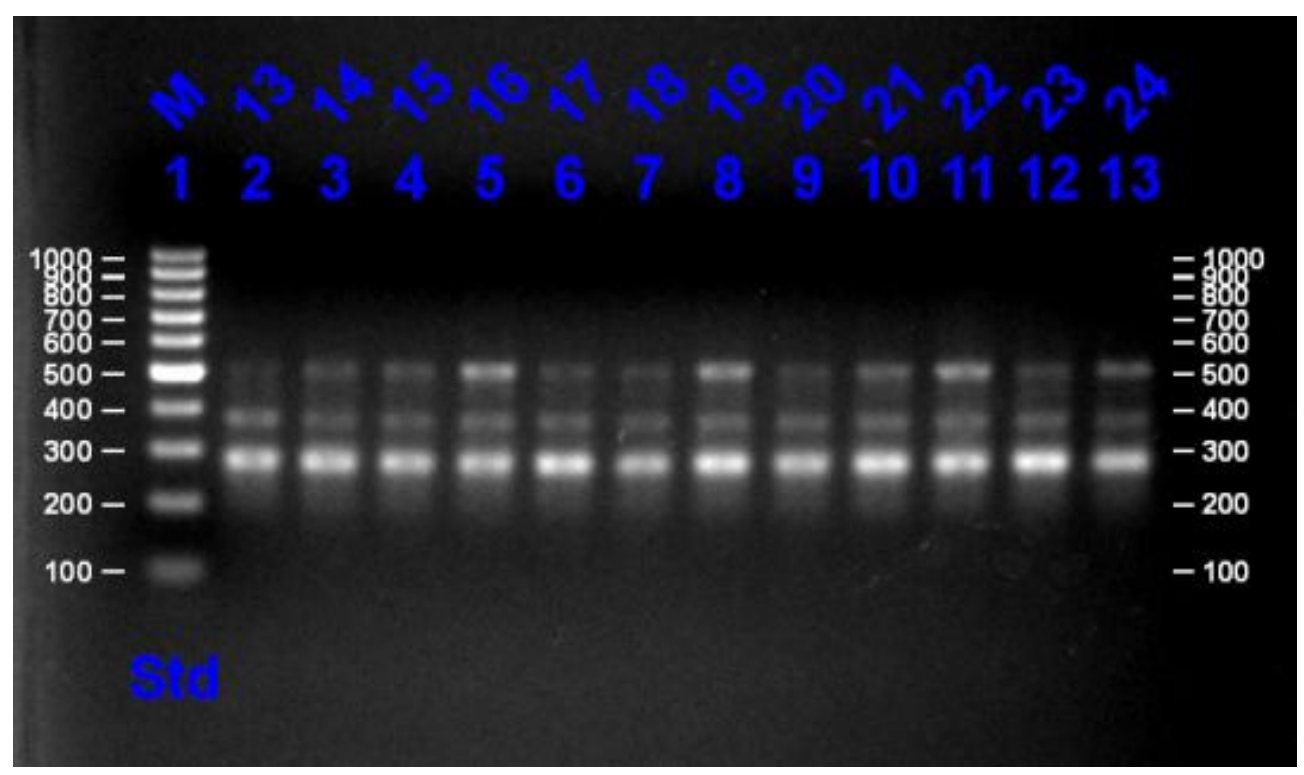


Primer OPH-17 gave the highest polymorphic bands i.e. 4 in both the groundnut group and the lowest were found in primer $\mathrm{OPH}-5, \mathrm{OPH}-$ 7, OPH-10, OPH-12, OPH-18 and OPH-19 with 1 polymorphic band each in Virginia group and in Spanish group primer OPH-5, OPH-7, OPH-10, OPH-12, OPH-15, OPH-18 and OPH-19 gave 1 polymorphic band each.

Out of the total number of 36 bands, 18 bands were polymorphic in Virginia group and in Spanish group out 37 bands produced, 20 were found to be polymorphic.

\section{Jaccard's similarity coefficient and cluster analysis}

The RAPD data were used to obtain the similarity matrix. For the Virginia group, the similarity coefficient for different genotypes lies in the range of 0.09 to 0.78 and in Spanish group similarity coefficient for different genotypes ranged from 0.13 to 0.88 .

In Virginia the minimum similarity (0.09) was observed between genotypes HNG 137 and ICGS 76; HNG 137 and ICGV 87846; the maximum similarity (0.78) was observed between genotypes JSP 48 and K1 451; K 1451 and $\mathrm{K}$ 1468. For Spanish group the minimum similarity (0.13) was observed between genotypes CSMG 2006-6 and J71; CSMG 2006-6 and RTNG 1; K 1470 and RTNG 1; J 71 and K1470 whereas the maximum similarity (0.88) were observed between Dh 218 and K 1392. A dendrogram was constructed using the similarity matrix value as determined from RAPD data for 24 groundnut genotypes each 12 Virginia and 12 Spanish within the group using UPGMA (Unweighted Pair Group Method of Arithmetic Mean). Cluster analyses for the two groundnut group are given below:

\section{Virginia group}

For the Virginia group, the dendrogram generated on the basis of Jaccard's similarity coefficient clearly indicated four clusters. The cluster I which was the major cluster included 6 genotypes viz., CSMG 2006-26, HNG 137, JSP 48, JSP 49, K 1451 and K 1468. The cluster II included 3 genotypes i.e. BAU 13, JSSP 37 and RG 578. The cluster III included 2 genotypes i.e. ICGS 76 and ICGV 87846 while cluster IV has only 1 genotype, i.e. RG 530.

\section{Spanish group}

For the Spanish group, the dendrogram generated shows five clusters. The cluster I included 4 genotypes i.e. CTMG 7, Dh 218, K 1333 and $\mathrm{K}$ 1392. The cluster II included 3 genotypes i.e. TCGS 876, TCGS 901A and TG 68 . The cluster III and cluster IV included 2 genotypes i.e. J 71 and UG 6; CSMG 2006-6 and K 1470 respectively. The remaining cluster V included only 1 genotype, i.e. RTNG 1 .

It has been a general observation that genetic diversity plays a major role in the expression of heterosis. Several scientists have shown that hybrids between genetically diverse parents manifest greater heterosis than those between more closely related parents (Ramanujam et al., 1974 in mungbean; Arunachalam et al., 1984 in groundnut; Rao et al., 2004 in sunflower; Parameshwarappa et al., 2012 in chickpea).

The study concluded that the genotypes which were under the different cluster for both the group can be utilized for future hybridization programme for groundnut improvement. RAPD can be successfully used for evaluation of divergence analysis in groundnut, however the effectiveness largely depends on the selection of the molecular markers. In our study, the analysis would have been more effective and meaningful if we have combined the analysis with other molecular markers. 


\section{Acknowledgements}

The authors are grateful to the College of Agriculture, Central Agricultural University, Imphal for providing facilities and support for conducting the experiment.

\section{References}

Anonymous 2011. Directorate of Economics and Statistics, Department of Agriculture and Cooperation.

Arunachalam, V., Bandyopadhyay, A., Nigam, S.N. and Gibbons, R. W. 1984. Heterosis in relation to genetic divergence and specific combining ability in groundnut (Arachis hypogaea L.). Euphytica. 33 (1): 33-39.

Bunting, A.H. 1955. A classification of cultivated groundnut. Empire J. Exp. Agric. 23: 158-170.

Bunting, A.H. 1958. A further note on the classification of cultivated groundnut. Empire J. Exp. Agric. 26: 254-258.

Colombo, C., Second, G. and Charrier, A. 2000. Diversity within America Cassava germplasm based on RAPD markers. Genet. Mol. Biol. 23: 189199.

Davila, J.A.Y., Loarce, E. and Ferrer 1999. Molecular characterization and genetic mapping of random amplified microsatellite polymorphism in Barley. Theor. Appl. Genet. 98: 265-273.

Ferreira, M.E. and Grattupaglia, B. 1996. Introdução ao uso de marcadores moleculares em análise genética. $2^{\text {nd }}$ edition embrapacenargen. Brasilla. 12: 121-130.

Jaccard, P. 1901. Étude comparative de la distribution floraledansune portion des Alpeset des Jura. Bulletin de la SociétéVaudoise des Sciences Naturelle. 37: 547-579.

Lashermes, P., Trouslot, P., Anthrony, F.,
Combes, M.C. and Charrier, A. 1996. Genetic diversity for RAPD marker using cultivated and wild accessions of Coffea arabica. Euphytica. 87: 59-64.

Parameshwarappa, S. G., Salimath, P. M., Upadhyaya H. D., Kajjidoni, S. T. and Patil, S. S. 2012. Heterosis in relation to genetic divergence in minicore collections of Chickpea (Cicer arietinum L.). Indian J. Genet. Plant Breed. 72(3): 303-308.

Porebski, S., Grant, L.B. and Bernard, R.B. 1997. Modification of a CTAB DNA Extraction Protocol for Plants Containing High Polysaccharide and Polyphenol Components. Plant Mol. Biol. Rep. 15(1): 8-15.

Powell, W.; Morgante, M. and Andre, C. 1996.The comparison of RFLP, RAPD, AFLP and SSR (microsatellite) marker for germplasm analysis. Mol. Breeding. 2: 225-238.

Ramanujam, S., Tiwari, A.S. and Mehra, R.B. 1974. Genetic divergence and hybrid performance in mungbean. Theor. Appl. Genet. 25: 211-214.

Rao Mohan, G., Reddy, L., Kulkarni, R.S., Ramesh, S. and Reddy Lalitha, S.S. 2004. Prediction of heterosis based on genetic divergence of parents through regression analysis in Sunflower. HELIA. 27(41): 51-58.

Rohlf, F.J. 1998. NTSYS-PC numerical taxonomy and multivariate analysis system, version 2.02.Exeter Software, Setauket, New York.

Russell, J.R., Fuller, J.D., Macaulay, M., Hatz, B.G., Jahoor, A., Powell, W. and Waugh, R. 1997. Direct comparison of levels of genetic variation among Barley accessions detected by RFLPs, AFLPs, SSRs and RAPDs. Theor. Appl. Genet. 95: 714-722.

Samec, P. and Nesinec, V. 1996. The use of RAPD techniques for the identification and classification of Pisum sativum L. 
genotypes. Euphytica. 89: 229-234.

Williams, J.G.K., Kubelik, A.R., Livak, K.J., Rafalski, J.A. and Tingey, S.V. 1990. DNA polymorphism amplified by arbitrary primers are useful as genetic markers. Nucleic Acids Res. 18: 65306535.

\section{How to cite this article:}

Yaikhom Vivekananda, Pramesh Khoyumthem, Mutum Suraj Singh, Konsam Cha Shyamananda and Brajendra Singh, N. 2019. Genetic Divergence in Groundnut (Arachis hypogaea L.) using RAPD. Int.J.Curr.Microbiol.App.Sci. 8(09): 1535-1549. doi: https://doi.org/10.20546/ijcmas.2019.809.176 